\title{
Risk practices and immunization against hepatitis B among female sex workers
}

\author{
Práticas de risco e imunização contra hepatite B em mulheres profissionais do sexo
}

Rosilane de Lima Brito Magalhães ${ }^{1}$, Vanessa Moura Carvalho' ${ }^{1}$, Giselle Mary Ibiapina Brito ${ }^{1}$, Layze Braz de Oliveira ${ }^{3}$, Marli Teresinha Gimeniz Galvão², Elucir Gir ${ }^{3}$

Objective: to identify the use of hepatitis B vaccine and risk practices among female sex workers. Methods: cross-sectional research using the Respondent Driven Sampling methodology. One-hundred and fifty-three sex workers were studied. Results: risk practices were related to the early onset of sexual activity, multiple partners with up to 17 clients per week 34 (22.2\%), lack of use of condom 9 (5.9\%), 124 (81.0\%) shared sharps and 53 $(34.6 \%)$ reported no vaccine against hepatitis B. Conclusion: sex workers found themselves exposed to various risk situations to the hepatitis B virus, due to the lack of immunization schedule, sexual precocity, multiple sex partners lack of use of condom, habit of sharing sharp objects. It is urgent to invest in health promotion with guidance on the importance of the vaccine, the adoption of protective measures and increased access of sex workers to health facilities.

Descriptors: Hepatitis B Vaccines; Women; Sex Workers.

Objetivo: identificar o uso da vacina contra hepatite B e práticas de risco entre mulheres profissionais do sexo. Métodos: pesquisa transversal, utilizando-se a metodologia Respondent Driven Sampling. Foram estudadas 153 profissionais do sexo. Resultados: as práticas de risco foram relacionadas ao início precoce de atividades sexuais, múltiplas parceiros com até 17 clientes por semana $34(22,2 \%)$, sem uso do preservativo $9(5,9 \%), 124(81,0 \%)$ compartilhavam objetos cortantes e 53(34,6\%) não reportaram vacina contra hepatite B. Conclusão: as profissionais do sexo encontravam-se expostas a várias situações de risco ao vírus da hepatite B, em função da falta de esquema vacinal, precocidade sexual, múltiplos parceiros sexuais sem uso de preservativo, compartilhamento de objetos cortantes. Urge investir na promoção da saúde, com orientação sobre a importância da realização da vacina, adoção de medidas protetivas e ampliação do acesso das profissionais do sexo às unidades de saúde.

Descritores: Vacinas contra Hepatite B; Mulheres; Profissionais do Sexo.

\footnotetext{
${ }^{1}$ Universidade Federal do Piauí. Teresina, PI, Brazil.

${ }^{2}$ Universidade Federal do Ceará. Fortaleza, CE, Brazil.

${ }^{3}$ Escola de Enfermagem de Ribeirão Preto, Universidade de São Paulo. Ribeirão Preto, SP, Brazil. 


\section{Introduction}

Hepatitis B is a serious public health problem worldwide. It is estimated that more than two billion people are infected with hepatitis B and 370 million suffer from chronic infection by this agent. The most common form of transmission is sexual transmission, but the acquisition of the virus can also take place parenterally, through contact with blood and other fluids of infected individuals, in a horizontal or vertical manner ${ }^{(1)}$.

The prevalence is higher in populations at risk such as homeless people, teenagers and sex workers, usually associated with the use of injecting drug, prostitution and early and unprotected sexual activity. Prevention against hepatitis B infection is linked to measures to prevent parenteral exposure to the virus, among which stand out the control of blood banks, instrument sterilization, harm reduction in intravenous drug users, personal protection of health professionals and sexual protection through condom use. Hepatitis B is one of the sexually transmitted infections that can be prevented by vaccine, the most effective measure when the three-dose schedule is followed $^{(2-3)}$.

In Brazil, the hepatitis B vaccine is available in public health network since 2013 for people up to 49 years of age and priority populations, regardless of age, including sex workers ${ }^{(2)}$. Despite the availability of the vaccine against hepatitis $B$, vaccination coverage does not happen universaly in the population and this contributes to more people exposed to the virus.

In the Brazilian context, immunization is free and studies have shown reduced immunization among sex workers. In the Midwest, $89.6 \%$ of sex workers had low vaccination coverage and poor adherence to hepatitis B vaccine ${ }^{(4)}$ While in Holland, a vaccination program implemented in 2002 to selective populations reduced the incidence of hepatitis B from 1.8 to $1.2^{(5)}$.

Lack of knowledge about the risk of hepatitis $B$, the access to health services and the cost of the vaccine, are factors that impede the access of the most vulnerable populations to immunization ${ }^{(6)}$. Associated with these factors is the risk behaviors adopted by sex workers, such as early and unprotected sexual activity, low education level and lack of use of condoms in all sexual relations, use of alcohol and drugs ${ }^{(3,5)}$. The vaccination is important to reduce infection.

In light of the above, the objective of the present study is to identify the use of hepatitis B vaccine and the risk practices among female sex workers.

\section{Methods}

This is a descriptive, cross-sectional study developed in areas of prostitution in the municipality of Teresina-PI, northeastern Brazil.

In Teresina, female sex workers have the support of the Prostitutes Association of the State of Piauí. Considering that this is a population organized in performance networks, female sex workers were included in this study through the Respondent Driven Sampling method which includes several key requirements to create a representative sample. First, we defined two persons of the target population with different characteristics in relation to the site of action in the central area of Teresina. One of the selected women worked in the square and the other in bars. They were called seeds. Each one received three unforgeable coupons and were told to recruit three women they knew in their group, and so on, until a representative sample was obtained. It was possible to recruit 153 participants.

The criteria for eligibility were: exercise of paid sexual practice, work in the central area of the city of Teresina and be 18 years old or older.

Data collection occurred in different prostitution sites (squares, bars and streets), from August 2014 to February 2015, in sites indicated by women that were included in the research.

In order to ensure uniformity in data collection, the women were interviewed by trained researchers, using the previously tested form whose variables 
of interest for this study were: sociodemographic (age, origin, monthly income, marital status, sexual orientation, education); behavioral (onset of sexual activity, number of sexual partners, condom use, hygiene); exposure (tattoos, blood transfusions, sharing of sharp objects); information (hepatitis, immunization against hepatitis B).

The variables were established according to the potential risk of acquiring sexually transmitted diseases and other injuries in the case of female sex workers. Thus, in order to evaluate the risk of acquiring hepatitis B were considered: type of sexual intercourse, condom use, hygiene, tattoos, blood transfusions, sharing of sharp objects ${ }^{(2,6)}$.

The status of vaccination against hepatitis B was defined according to the account of participants or, when possible, observed in vaccination records and taking into account the schedule recommended by the National Immunization Program ${ }^{(2)}$ of three doses $(0,1,6)$.

Data were entered in Excel sheets in double typing. After validation, data were exported to the Program Statistical Package for Social Science version 20.00 and descriptive statistics were carried out: absolute frequency, relative frequency, mean and median and standard deviation.

The study complied with the formal requirements contained in the national and international regulatory standards for research involving human beings.

\section{Results}

Among the 153 sex workers, age varied between 18-56 years (minimum age $=18$, maximum age $=56$ ), most were single ( $81.7 \%$ ), with $<8$ years of schooling (98.0\%), 43.1\% informed financial income up to one minimum wage. The minimum wage at the time the study was R\$788.00, equivalent to U\$291.85. With regard to sexual orientation, $94.1 \%$ reported being heterosexual, $3.9 \%$ homosexual and $0.7 \%$ bisexual. Regarding the place of work, $48.4 \%$ worked in squares,
45.8\% in bars and 5.9\% on the street.

The following information were observed in the assessment of behavior that has risk of acquiring hepatitis B: 135 (88.1\%) participants reported their first sexual intercourse before the age of 16 (minimum age $=10$ years; maximum age $=23$ years). The number of customers per week ranged from 1 to 17 , with a higher proportion (61.8\%) 13 to 17 week partners. The constant use of condoms was reported by 144 (94.1\%), tattoos was reported by 42 (27.5\%) and the sharing of sharp objects was reported by 124 (81.0\%) women. Only one sex worker reported that she had received blood transfusion.

When the practice of hygiene after sexual encounters with clients was investigated, all informed that they make use of shared bathrooms. However, 12 (7.8\%) did not perform body hygiene, but reported change of sheets and towels, 127 (83.0\%).

Regarding knowledge on the type of hepatitis, $94(61.4 \%)$ reported that they had knowledge of the infection. Hepatitis A and B were the most reported, 58 (37.9\%). Among them, 105 (68.6\%) have never conducted tests or prior examination for hepatitis B (Table 1).

Table 1 - Knowledge of 153 female sex workers about hepatitis

\begin{tabular}{lcc}
\hline Variables & $\mathbf{n}(\mathbf{\%})$ & CI (95\%) \\
\hline know hepatitis & $94(61.4)$ & $(53.7$ to 69.1) \\
$\quad$ Yes & $59(38.6)$ & $(37.97-39.22)$ \\
$\quad$ No & & \\
Know hepatitis A & $8(5.2)$ & $(1.7-8.7)$ \\
$\quad$ Yes & $145(94.8)$ & $(91.3-98.3)$ \\
No & & \\
Know hepatitis B & $36(23.5)$ & $(16.8-30.2)$ \\
Yes & $117(76.5)$ & $(53.4-99.5)$ \\
No & $18(11.8)$ & $(11.3-12.2)$ \\
Know hepatitis C & $135(88.2)$ & $(6.7-16.8)$ \\
$\quad$ Yes & & \\
No & $21(13.8)$ & $(83.1-93.3)$ \\
Knows more than one type of hepatitis & & \\
Yes & $132(86.2)$ & $(70.9-101.4)$ \\
No & & \\
Shes has done tests for hepatitis B & $48(31.4)$ & $(24.39-38.40)$ \\
Yes & $105(68.6)$ & $(67.95-69.25)$ \\
No & & \\
\hline
\end{tabular}


Specifically in relation to the investigation of previous immunization against hepatitis B, 53 (34.6\%) female sex workers had not received the vaccine dose, $80(52.3 \%)$ received the first dose of the vaccine, 9 (5.9\%) received the second dose of vaccine and only $11(7.2 \%)$ reported having completed the vaccination schedule. During the study, 142 participants received one or more doses of the vaccine regardless having started or not the vaccine schedule.

\section{Discussion}

Female sex workers are exposed to various behaviors that present risk of acquiring hepatitis $\mathrm{B}$, depending on the precocity of sexual activity, multiple partners, non-use of condoms, sharing of sharp objects, and low immunization coverage against hepatitis B.

Early onset of sexual activity represents a increased risk for sexually transmitted infections and unwanted pregnancy. Data from this study and from different regions of the world have similarity regarding precocity of the first sexual intercourse. In China, $30.8 \%$ of female sex workers reported having their first sexual experience before the age of $18^{(7)}$. In southern Brazil, female sex workers, $59.8 \%$, mentioned the first sexual intercourse before completing 15 years $^{(8)}$.

Most participants had low education. A similar situation was found in Shanghai, China, where 470 (78.4\%) out of 600 female sex workers had not completed high school ${ }^{(7)}$. In southeastern Brazil, female sex workers reported an average of nine years of study ${ }^{(8)}$. A study conducted in 10 cities of Brazil showed higher levels of education among women who are in closed environments such as bars and nightclubs ${ }^{(9)}$. This suggests that women who are in open environments such as streets and squares have greater vulnerability to hepatitis B.

Financial income with sex work, measured by the monthly income rate, was also variable in this study. Research conducted in China showed higher values than those found in this study, where 389 (64.8\%) of participants had monthly income from 2 to 4 minimum wages ${ }^{(7)}$. It is said that younger and more educated women develop sexual work indoors and have better monthly income ${ }^{(9)}$. Most participants worked in squares and bars. Study carried out in the Midwest Region of Brazil showed that five out of the six cases of HIV detected were women working on the streets $^{(10)}$.

In this study, the number of weekly customers ranged from 0 to 17 , with higher frequency of 34 $(22.2 \%)$ respondents who reported having 13 to 17 customers in the week preceding the data collection. In China, when asked about the number of sexual partners, 33.8\% female sex workers reported having more than 21 sexual partners during the year. In São Paulo, the average number of customers was two per day, ranging from 1 to $30^{(7,11)}$. Another study conducted in 2010 in Goiania, capital of the Midwest of Brazil, with 395 participants, showed that half of sex workers reported more than seven sexual partners (including stable partners and customers) in the week preceding the interview. These research studies show that the multiplicity of partners in this profession is high, producing greater vulnerability to risks in the course of prostitution, regardless of the place in the world. Thus, the risk is potentially greater when there is low adherence to the use of condoms in all sexual relations.

The lack of protection in sexual intercourse constitutes a risk factor for the transmission of sexually transmitted infections. This makes the consistent use of condoms necessary to reduce the risk. In turn, female sex workers are exposed to the partner's willingness to use it, because the value of the program may be related to lack of protection. Because of the precarious financial condition of women, they opt for unprotected sex with clients.

In the present study, protected sexual practices were linked only to sexual activity with casual 
partner but not with fixed partner. Among them, $5.9 \%$ participants said they do not use condoms in relationships. The proportion was much higher in China, where only $47.5 \%$ of women said they used condoms consistently ${ }^{(7)}$. In occasional paid and occasional sex practices, the women who are sex workers have no power of decision and freedom in their sexual life, and thus they are exposed to acquire various infections in every unprotected sexual relationship. Associated with the acquisition of other sexually transmitted diseases, these women are also exposed to unwanted pregnancy.

In this study, access to condoms occurred through public health services (26.7\%). However, the majority (35.9\%) purchased condoms in pharmacies, using their own resources. Study showed that receiving the condom is more common in women who recruit customers on the street and that they are more exposed to Sexually Transmitted Infections ${ }^{(9)}$. The findings show the importance of expanding prevention measures for female sex workers and of improving the access to public health services.

Study of 664 adolescents aged between 11 and 19 years found an overall prevalence of hepatitis B of 5.9\%. In addition, the study showed that older adolescents (16-19 years old) were 3.6 times more likely to be exposed to hepatitis B infection than younger individuals ${ }^{(12)}$.

Another study in the Midwest region of Brazil with 150 users of injecting drugs that had the aim to analyze the risk factors associated with hepatitis B and previous vaccination status against this infection showed that $20.6 \%$ users had been exposed to Hepatitis B virus; one was HBsAg-positive, 18 were anti-HBc/anti-HBs reactive and 12 were positive only for anti-HBc. Only 9 (6.0\%) were positive for anti-HBs ${ }^{(13)}$. This situation shows that vulnerable populations are more exposed to hepatitis $B$.

In this study, $27.5 \%$ of women had made tattoos throughout their lives. In a city in the Midwest region of Brazil, more than two thirds of the of 395 women had tattoos and/or piercings ${ }^{(10)}$.

The sharing of sharp objects such as pliers and nail scissors is also a risk factor for acquiring hepatitis B. Just as the instruments used to perform tattoos, these objects can come into contact with potentially contaminated blood and body fluids. In this study, the results showed that sharing sharp objects was a practice of most of the women $(81.0 \%)$ and the risk of acquiring and transmitting infection was present in this population.

Because hepatitis B is a grievance with high potential for prevention, health strategies should continuously be programmed, as well as clarification of transmission modes, training for tattooists, for manicures, for sex workers, among others. Most importantly, the process of immunization should encouraged because hepatitis $B$ vaccination is the most effective way to anticipate and control the infection.

Regarding knowledge on hepatitis B, 94 (61.4\%) respondents said they knew the infection. Hepatitis A and B were the most reported, 58 (37.9\%). The majority of women, represented by 105 (68.6\%) women, never made prior examination for hepatitis B and $48(31.4 \%)$ said they had made.

In this study, only $7.1 \%$ women reported having received three doses of vaccine, $52.2 \%$, the first dose, and $5.8 \%$, the second dose. During the research, immunization was offered and, $35.9 \%$ accepted the invitation and were vaccinated.

In Indonesia, a study shows that among sex workers, 8 (4\%) were seropositive for HBsAg and 128 $(64.0 \%)$ for anti-HBc ${ }^{(14)}$. This demonstrates that these professionals were more exposed to this infection.

In a study conducted in southern Brazil, the rate of infection by hepatitis B virus was detected in $23.1 \%$ of the study population ${ }^{(11)}$. This demonstrates high prevalence of preventable infection through vaccine.

The lack of coverage of this population by primary care services may contribute to increased vulnerability to hepatitis B. In Lisbon, the Civil 
Society Organization takes actions to prevent Sexually Transmitted Infections in professional female sex workers. This organization focuses on actions aimed at customers, guides the policies of projects of prevention in a more holistic and comprehensive approach, aiming to improve the access for people without legal documentation and combat the social stigma against this population ${ }^{(15)}$.

Despite the fact that the vaccine is the most effective free protective strategy available, few of these women had been vaccinated against hepatitis B and they have difficulty in completing the vaccination schedule of three doses. In Brazil, a study with 721 female sex workers found that $27.6 \%$ of them had not been vaccinated against hepatitis B; $60.1 \%$ were eligible for vaccination, and, still, only $37.5 \%$ had received all three doses of the vaccine $\mathrm{e}^{(4)}$. A survey conducted in six countries showed differences in vaccination practices and found no vaccine record against hepatitis $\mathrm{B}$ and/or in less than half the population. Therefore, the implementation of training on vaccination for health professionals and graduate students is suggested ${ }^{(11)}$. The low coverage and/or absence of vaccination against hepatitis B in female sex workers is a serious problem in the world and contributes to greater exposure to hepatitis B infection.

\section{Conclusion}

Female sex workers had risk factors for acquisition of hepatitis B due to the early onset of sexual activity combined with multiple partners, lack of use of condoms, sharing of sharp objects and low level of education, factors that amplify the chances of contracting sexually transmitted infections, including hepatitis. About hepatitis B vaccine, even though this is available in health services and it is indicated for sex workers, there was low immunization coverage and poor access to health services.

\section{Acknowledgements}

To the Department of Sexually Transmitted Diseases/AIDS and Viral Hepatitis of the Ministry of Health of Brazil, the United Nations Office on Drugs and Crime and the National Council for Scientific and Technological Development for the support and funding process noㅜ 459935/2014-3.

\section{Collaborations}

Magalhães RLB contributed to the project design, article writing, relevant critical review of the intellectual content and final approval of the version to be published. Carvalho VM, Brito GMI and Oliveira LB contributed to the collection and analysis of data. Galvão MTG and Gir E contributed to the writing of the article and relevant and critical review of the intellectual content.

\section{References}

1. Pudelco $\mathrm{P}$, Koehler $\mathrm{AE}$, Bisetto LHL. Impact of vaccination in the reduction of hepatitis $B$ in Paraná. Rev Gaúch Enferm. 2010; 35(1):86-6.

2. Ministério da Saúde (BR). Secretaria de Vigilância em Saúde. Departamento de Vigilância Epidemiológica. Hepatites virais: o Brasil está atento. Brasília: Ministério da Saúde; 2010.

3. Romano L, Paladini S, Van Damme P, Zanetti AR. The worldwide impact of vaccination on the control and protection of viral hepatitis B. Dig Liver Dis. 2011; 43(Supl 1):2-7.

4. Carneiro LM, Mousquer GJ, Pinheiro RS, Castro AR, França DD, Caetano KA, et al. Outreach hepatitis $B$ vaccination of female sex workers in central-west Brazil: immunization status, compliance, and immune response. J Public Health Manag Pract [Internet]. 2014 [cited 2015 Jul 01]; 20(6):662-6. Available from: http://www.ncbi. nlm.nih.gov/pubmed/24378607 
5. Hahné S, Van HR, Koedijk F, Van Ballegooijen M, Cremer J, Bruisten S, et al. Selective hepatitis $B$ virus vaccination has reduced hepatitis $B$ virus transmission in the Netherlands. Plos One [Internet]. 2013 [cited 2013 Jul 29]; 8(7). Available from: http://www.ncbi.nlm.nih.gov/ pubmed/23922651

6. Centers for Disease Control and Prevention. Hepatitis B: epidemiology and prevention of vaccine- preventable. Diseases [Internet]. 2015 [cited 2015 Jul 01]. Available from: httt:/www. cdc.gov./vaccines/pubs/pinkbook

7. Zhang T, Yang Y, Feng Y, Zhao Y, Lin F, Minhas V, et al. Kaposi's sarcoma associated herpes virus infection among female sex workers and general population women in Shanghai, China: a crosssectional study. BMC Infect Dis [Internet]. 2014 [cited 2015 Jul 01]; 14(18). Available from: http:// www.ncbi.nlm.nih.gov/pubmed/24498947

8. Pogetto B, Rodrigues M, Silva MG. Prevalence of sexually transmitted diseases in female sex workers in a city in the interior of São Paulo, Brazil. Rev Latino-Am Enfermagem. 2011; 19(3):493-9.

9. Damacena GN, Szwarcwald CL, Souza Junior PRB. Práticas de risco ao HIV de mulheres profissionais do sexo. Rev Saúde Pública. 2013; 48(3):428-37.

10. Caetano KA, França DD, Carneiro MA, Martins RM, Stefani MM, Kerr LR, et al. Prevalence and virologic profile of HIV infections among female sex workers in Goiânia City, Central Brazil. AIDS Patient Care STDs [Internet]. 2013 [cited 2015 Jul 01]; 27(1):1-4. Available from: http://www.ncbi. nlm.nih.gov/pubmed/23066700
11. Schuelter-Trevisol F, Custódio G, Silva AC, Oliveira MB, Wolfart A, Trevisol DJ. HIV, hepatitis B and C, and syphilis prevalence and coinfection among sex workers in Southern Brazil. Rev Soc Bras Med Trop. 2013; 46(4):493-7.

12. Alexandre KVF, Martins RMB, Souza MM, Rodrigues IMX, Teles SA. Brazilian hepatitis B vaccine: a six-year follow-up in adolescents. Mem Inst Oswaldo Cruz [Internet]. 2012 [cited 2015 Aug 01]. 107(8): 1060-3. Available from: http:// www.ncbi.nlm.nih.gov/pubmed/23295759

13. Matos MAD, Ferreira RC, Rodrigues FP, Marinho TA, Lopes CLR, Novais ACM, et al. Occult hepatites $B$ virus infection among injecting drug users in the Central-West Region of Brazil. Mem Inst Oswaldo Cruz [Internet]. 2013 [cited 2015 Dec 20]; 108(3):386-9. Available from: http://dx.doi. org/10.1590/S0074-02762013000300019

14. Kotaki T, Khairunisa SQ, Sukartiningrum SD, Arfijanto MV, Utsumi T, Normalina I, et al. High prevalence of HIV-1 CRF01_AE viruses among female commercial sex workers residing in Surabaya, Indonesia. PLoS One [Internet]. 2013 [cited 2015 Feb 01]; 8(12). Available from: http:// journals.plos.org/plosone/article?id=10.1371/ journal.pone.0082645

15. Maia M, Rodrigues C. Civil society organizations in the prevention of sexually transmitted infections among female sex workers, in Portugal. Saúde Soc [Internet]. 2014 [cited 2015 Feb 01]; 23(1):114. Available from: http://dx.doi.org/10.1590/ S0104-12902014000100006 